\title{
The use of spiritual resources to cope with trauma in daily existence
}

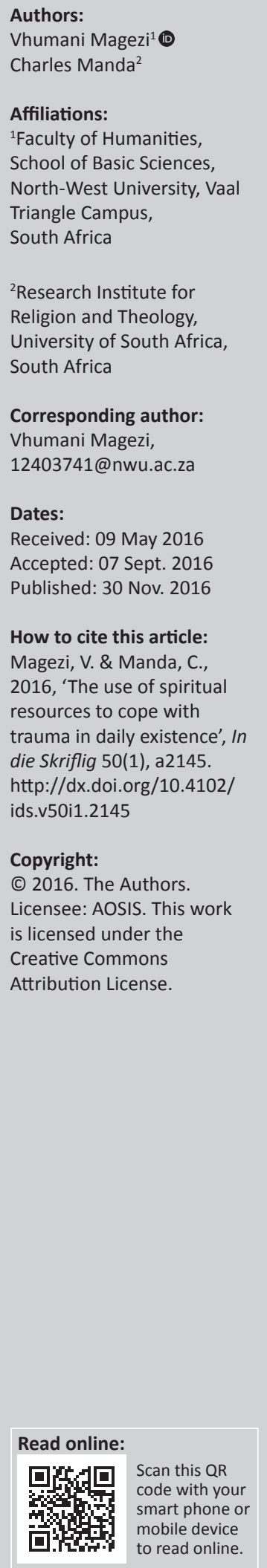

The article explores the link between trauma and spirituality, and investigates whether and how spirituality can be used as a resource to address the needs of people in traumatic situations. The authors address the following questions: Why is it that spirituality and God himself may seem to make little or no sense to people who are experiencing trauma? Is spirituality an abstract concept that lacks practical relevance in crisis situations? Do peoples' understanding of God and what they believe about his nature and power affect their spirituality and determine how they understand God's intervention in coping with trauma? To answer these questions, the authors make use of the life history research method to analyse the case of Nokwazi Chiya, a Zulu woman who abandoned God and all spiritual support systems after the traumatic death of her fiancé. The findings demonstrate how traumatic events destroy not only the psychosocial aspects, but also the survivor's faith in a natural or divine order and cast the survivor into a state of existential crisis. The findings further show the role spirituality plays in enhancing the healing, recovery and developing resilience of trauma survivors. The study subsequently argues for an integrated approach to working through trauma, which brings spirituality into the psychotherapeutic dialogue - particularly in the South African context, where the majority of the population is exposed to various types of trauma. This integrated psychotherapy approach will have implications for the disciplines of practical theology and psychology or psychiatry, especially with regard to how we understand, assess and treat the needs of different people exposed to trauma and other existential crises.

\section{Background and premise}

Using the life history research method, this article draws on the case study of Nokwazi Chiya, ${ }^{1}$ a research participant in Manda's (2013) longitudinal PhDstudy which took place in Pietermaritzburg between 2009 and 2013. Chiya's story titled, 'On my strong shoulders', was published in the collection of stories, Trees along the riverside: The stories of trauma facilitators in KwaZulu-Natal South Africa (Haarhoff 2013). After losing many loved ones, including two fiancés, the death of Chiya's third fiancé alienated her from God and all spiritual support systems. Bitter at God's inability to intervene, in spite of her prayers and pleading with God for his life, Chiya abandoned God, the church and spiritual rituals for two years. She later reconciled with God and her spiritual support systems. Spiritual support system refers to the church community and related circle of friends drawn from the church community. Through her case, the authors explore why spirituality and God himself may seem to make little or no sense to people who are experiencing trauma. Specifically the authors address the following questions: Do peoples' understanding of God and what they believe about his nature and power affect their spirituality and how they understand God's intervention in coping with trauma? Can spirituality be used as a resource to enhance the health and well-being of trauma survivors? Spirituality relates to devotion and piety. Many theological scholars such as Louw (2013:4), Waaijman (2003:315-317) and Stevens and Green (2003:x) clarify that spirituality concentrates on those human acts in which the reference to God is not only explicit but also immediate.

Recent studies conducted among trauma survivors in South Africa have tended to focus on establishing the presence of posttraumatic disorder (PTSD), and sometimes, depression - a focus which is in keeping with international studies that have shown that these disorders are commonly found among trauma survivors (Kaminer \& Eagle 2010:56). This finding is also highlighted by Atwol et al. (2013:1) in their study, Trauma and posttraumatic stress disorder in South Africa: Analysis from the South African stress and health study. In their book, Traumatic stress in South Africa, Kaminer and Eagle (2010:56) maintain that local (South African) studies have 1.Nokwazi Chiya was a research participant in Manda's (2013) longitudinal PhD study. From here on she will be referred to as Chiya. 
consistently found very high levels of PTSD and depressive symptomatology across various groups of trauma survivors. These findings build on Buckenham's (1999:7-8) which revealed that South African society is a deeply traumatised community where each person has a traumatic story to tell about themselves, their friends, or their family. Buckenham (1999) found that trauma survivors had little energy, space or time to devote to healing their wounds because their daily survival in an increasingly difficult economic environment frequently added to already-present emotional and psychological trauma and rage.

These responses to traumatic events suggest that South Africans are burdened by exposure to trauma. Since increased trauma among South Africans is strongly related to an increase in levels of general distress, it is likely that many trauma survivors in South Africa experience psychiatric symptoms that are, in fact sub-clinical, or below the threshold for diagnosis. These sub-clinical symptoms may nonetheless reduce the quality of life of trauma survivors in many ways (Kaminer \& Eagle 2010:57). Citing the attempts made by South African researchers to explore the psychiatric effects of trauma more broadly, Kaminer and Eagle (2010:57) point out that somatic symptoms appear to be commonly reported. These findings are consistent with Edwards' (2005:125) review of specific clinical and epidemiological literature, which revealed that PTSD and its related conditions are a significant public health dilemma in South Africa and Africa at large (Manda 2014: 123-124 ). Studies of Sudanese refugees in Uganda and survivors of torture in Malawi (Martin \& Kagee 2008; Olley, Seedat \& Stein 2006), for example suggest that the impact of trauma among South Africans and those living in other countries in Africa may be more extensive than what emerges from a narrow focus on PTSD or depression.

Edwards (2005:125) concludes that PTSD is a significant public health concern, based not only on the prolific occurrence of PTSD in South Africa, but also on its debilitating effects which have a marked impact on different areas of human and societal functioning. Although Edwards focuses on PTSD, Kaminer and Eagle (2010) argue that there are many aspects of the effects of trauma in South Africa that need to be investigated. One such aspect that the current study seeks to better understand is the link between trauma and lived religion or spirituality. Trauma in South Africa is significantly experienced when an individual experiences the unexpected death of a loved. Atwol et al.'s (2013) study findings clearly make this 'loss of loved one triggered trauma' an important area of study. They noted that the most common traumatic events in South Africa are the unexpected death of a loved one as well as witnessing trauma occurring to others in that situation (2013:1).

Although research into the fields of trauma and spirituality has emerged in the past few decades, not much has been written on the link between these two concepts in South Africa. It is important therefore to explore the link between these two aspects and draw their implications to trauma healing. Accordingly, this article makes a contribution to healing of pain and suffering among people affected by trauma. It focuses on the interplay and interrelationship of God images and spirituality resources to achieve healing.

\section{Methodological approach}

In order to address the main aim of this study, the life history research method is used. Watson and Watson-Franke (1985:2) define life history as 'any retrospective account by the individual of his or her life in whole or part, in written or oral form'. Life histories are important for postmodern challenges to grand narrative since they can create multiple and diverse 'little narratives' that contest 'the stability of received knowledge' (Gardner 2002:28; Lewis 2008:562). Because of the narrative nature of life histories, this study assumed a broader narrative approach. Müller (2004:294-296) states that:

the narrative or social constructionist approach [...] forces us to first listen to the stories of people struggling in real situations, not merely to a description of a general context, but to be confronted with a specific and concrete situation. (pp. 294-296)

Elliott (2005:3) contends that a narrative 'organise[s] a sequence of events into a whole so that the significance of each event can be understood through its relation to that whole' and thereby becomes a tool for conveying 'the meaning of events'. Chiya's life history, however, left some gaps that challenged the coherence, or as Elliot (2005:3) puts it, 'a sequence of events' of her story. As such she was interviewed by the authors on 25 April 2015 in Pietermaritzburg in order to address the coherence issues in her story. The face-to-face interview technique provided a greater capacity for the correction of misunderstandings and gaps that existed in the published narrative (Bell 2003:102). Chiya's life history was purposively selected for this study because it demonstrates how her understanding of God affected how she coped with the traumatic loss of her fiancé. In the remaining sections, an excerpt of her published story is presented as a case study supplemented by data from the face-to-face interview.

\section{An analytical framework of trauma - a theory of God-images}

To understand the link between trauma and spirituality, it is vital to understand the theory of God-images. In this regard this study adopts Louw's (1998) theory of God-images, as set out in A pastoral hermeneutics of care and encounter: A theological design for a basic theory, anthropology, method and therapy. The distinction between God-concepts and God-images as Louw (1998:329) explains is that God-concepts refer to an intellectual, mental dictionary-definition of the word God, whereas a Godimage is a psychological working internal model of the sort of person that the individual imagines God to be. Hoffman et al. (n.d.:1) describe God-images as a person's experiential understanding of God. These God-images develop parallel to the God-concept of a person but through different means. Hoffman et al. (n.d.:1-2) added that while the God-concepts 
develops from what people are taught, the God-image develops through what people experience. They further clarify that traditionally it has been viewed that the Godimage develops primarily through how a child experiences their primary care giver or parents. The God-image is generally theorised to be more of a latent construct, while the God-concept is more of a manifest construct.

According to Mbiti (1970:xiii-xiv), concepts of God spring from reflections on God and are 'influenced naturally, by geographical, historical, cultural, and social-political factors'. However, Mbiti (1970) does not exclude the role that religious and philosophical wisdom plays in the development of concepts of God. He (1970) further argues that because these factors parallel similar factors in other countries and continents, the concepts of God in different countries and continents parallel those of other societies. He gives an example of the biblical concepts of God, and in particular those that are mentioned in the Old Testament. However, the discussion on the search for God-images particularly in Africa, have tended to swing to a Christological debate. In attempting to have a God in Christ who has an African Godimage, Oborji (2008:16) observed that many African theologians have designated 'Jesus as the liberator, the ancestor, the healer, the African king and the African chief'. The treatment of Christ under the category of ancestor is viewed by Wacheche (2012:27) and Oborji (2008:16) as the leading African Christological approach that many African theologians tend to follow.

Although Louw (2000:329) argues that it is difficult to distinguish between God-concepts and God-images because of the decisive role they play in both the cognitive and affective components of contextual situations. He maintains that God-concepts refer to the more systematic interpretation of God (dogmatics) and God-images to the more personal and individual experience of God. While concepts of God may be similar in different societies as Mbiti (1970) argues, Louw (2000:325-330) contends that God-images are not inherited but rather develop as individuals experience God in their various contexts. This makes the criteria for identifying and assessing God-images complex because over and above the factors that Mbiti (1970) mentions, other factors such as ecclesiastical confessions and dogmas, questions about philosophical and anthropological concepts and contextual issues such as personal issues related to selfesteem and emotional experiences, may also play a role (Louw 2000:325-330). As such he argues that there is no 'pure' concept or image of God that exists that could communicate God credibly and meaningfully.

In describing how God-images develop, Louw (2000:329) first points out that often the God-image is largely a projection of (favourable or unfavourable) parent images or personal need expectations. It is important to note that God-images are not static; they can change over a time in accordance with human developmental changes. A good example is children. Schneider (1997:233) points out that children will often opt for an image which portrays God as a protective guardian and reflects their need for parental caring. Schneider adds that God-images are often anthropomorphic, but become more refined and oriented to norms and values as one grows older and more mature. With old age, God-images are intertwined with wisdom and our human quest for meaning, and within the experience of Christian faith; God-images are the fabric of a believer's life story.

Secondly, Louw (1998:330) argues that God-images are linked to the individual's experiences of God within specific contexts. He cautions that God-images do not reflect the essence of God in terms of an ontological paradigm, but reflect God's actions and style (his mode) as experienced by believers according to real life events. A good illustration of this is the story of Kushner (1981), a rabbi who authored the book, When bad things happen to good people. Kushner testifies about his struggle to understand God when his son was diagnosed with progeria - a 'rapid aging' disease. Kushner's helplessness to avert the situation provoked theodicy questions in which he contested the stability of received knowledge' both as a religious Jew and as a rabbi. Kushner (1981) argued with God:

I had been a good person. I had tried to do what was right in the sight of God. More than that, I was living a religiously committed life than most people I knew, people who had large, healthy families. I believed that I was following God's ways and doing his work. How could this be happening to my family? If God existed, how could He do this to me? (p. 4)

His son's illness shattered his God-images, and he continues his arguments:

Like most people, my wife and I had grown up with an image of God as an All-wise, All-powerful parent figure who would treat us as our earthly parents did, or even better ... He would protect us from being hurt or from hurting ourselves, and would see to it that we got what we deserved in life. (pp. 5-6)

He reasoned:

Tragedies like this were supposed to happen to selfish, dishonest people whom I, as a rabbi, would then try to comfort by assuring them of God's forgiving love. How could it be happening to me, to my son, if what I believed about this world was true? (pp. 5-6)

Kushner illustrates the point Louw (2000) is making. His experience of God's silence or his inability to protect his son from the rapid aging disease did not affect the ontology (being) of God. It was his images of God 'as an All-wise, Allpowerful parent [protective] figure' that were affected, and even shattered.

Thirdly, Louw (1998:330) points that 'God-images are also determined by hermeneutics: the understanding and reading of scriptural texts'. As people read scriptural or biblical texts about the ways and works of God and his interactions with human beings and nature, one picks up certain manifestations, images and conceptions of whom God is. Is spirituality an abstract concept that lacks practical relevance in crisis situations? According to Kushner (1981), he kept his side of 
the promise. Why then did God allow the rapid aging disease to attack his son? He argues his case before God:

I had been a good person. I had tried to do what was right in the sight of God. More than that, I was living a religiously committed life ... How could this be happening to my family? If God existed, how could He do this to me? (p. 4)

The God-images Kushner adapted or incorporated did not match his experience, and therefore his God-images were crushed.

Fourthly, Louw (2000:329) points out that God-images are a complex issue within which cultural concepts, ecclesiastical confessions and dogmas and questions about philosophical and anthropological concepts play an important role. He maintains that this complexity means that no 'pure' concept or image exists which could communicate God credibly and meaningfully. Mbiti (1970:xiii) conducted a study on concepts of God in Africa in which he studied the traditional religious and philosophical wisdom of over 270 different people (tribes). He came up with God-concepts that each tribe uses to describe God. These concepts are based on the nature, attributes, providence, sustenance, and governing work of God. Mbiti's (1970) findings lend support to Louw's argument regarding the complexity of concepts and images of God.

Having outlined the perspective of God-images, we now proceed to consider the case study.

\section{A case study of Nokwazi Chiya}

As stated earlier, the main aim of this research is to explore the link between trauma and spirituality. To do this, this study draws on the case study of Chiya (2013) in order to answer the following questions: What theologies and spiritual values emerge when Chiya is confronted with the impending death of her fiancé? What role do her God-images play in her healing and recovery from the grief she experienced because of the traumatic death of her fiancé? How does her spirituality determine how she copes with the trauma of losing her fiancé?

Chiya, who was born on Sunday, 16 August 1970 at Edendale Hospital, was raised in the KwaMpumuza location in Phayiphini, KwaZulu-Natal, South Africa - a rural area under Chief Nsikayezwe Zondi. Chiya is the eldest of six children - three of whom are girls and three are boys. Her mother and father are from the Xhosa and Zulu tribes of South Africa respectively. She grew up in her grandmother and grandfather's house and did not know her father until the age of six, when he brought her a bicycle. Growing up in a Christian home and with a grandmother who was the wellknown Umthandazi [prayerful woman] in her community and church, Chiya was raised to be Christian. In her story she describes how she learnt from a young age to pray to God and to believe in God for answers.

Between 2009 and 2013, Chiya took part in Manda's (2013) PhD research project (Trauma Healing Project) which was conducted in Pietermaritzburg. During the project 14 of the
38 participants documented and published their stories in a book, which included Chiya's story. The documenting of the participants' stories formed part of the trauma healing process. In this regard Haarhoff (2013107-108), the editor of the book, writes:

Trauma can often leave us stuck. That is why telling and writing a story is important, for stories are about movement, about what is going to happen next. They help us become curious about our lines, move on to the next stage of grieving and enter the cycle of loss, healing and regeneration. (p. 4)

As background to Chiya's story, she states that she had two previous fiancés - both of whom died. She then met her third fiancé, whom she loved very much, and with whom she had a child. Unfortunately Chiya's third fiancé also died, despite her prayers to God for his recovery. The excerpt of Chiya's (2013:107-118) story is indicated below. While the story could be summarised in the interest of space, it has been maintained verbatim in order to draw clear lessons:

[I]n 1999 he became sick. We thought it was flu so Dr Tutu, his practitioner, tried to help him. In 2000 the doctor called my mum and said that my fiancé was in a poor condition. I left home to stay with him in Durban. By that time our son was doing Grade 2 so I stayed in Durban for two weeks, then went back for two days to do the washing and other chores at home.

On 22 March 2001 he was admitted to St Aidan's Hospital. He was on a drip because he had a running stomach and was dehydrated. I stayed with him morning till night. Whenever I tried to pray my sorrows were flooded in tears. I asked God, 'Ukuthi, why mina?' [Why me?] When will I find happiness in my life?

On Tuesday 27 March I received a voice message from the hospital. 'Come'. On the way my phone rang again. I was traumatised to see the hospital number. Then his friend called and asked me to meet at his workplace. The friend broke the news. The hospital had also called him to say that my fiancé had passed away.

'This cannot be true. He was not so sick when I last saw him,' I replied.

He asked for my mum's telephone number to call her. My mum screamed on the phone crying, 'When did this happen?' He told her it was around 3 a.m.

At the hospital they took me to the mortuary. My heart bled to see him lying on that cold shelf. They gave me the death certificate form to fill in for Home Affairs for without that certificate I could do nothing. By the grace of God I handed it in and closed all his accounts.

Nothing is impossible if you believe in God. Yet to tell the truth! Unkulunkulu [God] each and every time I look at our child, his father's death put my life on hold. On the 1 April 2001 his body was laid to rest in Howick Cemetery, the saddest day of my life. I told myself that God did not love me so I broke away from church for almost two years. I did not pray and if anyone mentioned God, I swore.

Then one day my cousin came to my house and called me back. 'You need to come to church. We are having visitors at church.' So I went but refused to wear my church uniform. As I heard the word of God, there was an inner argument inside me. The preacher's words were true but I struggled to accept them. On that day I came into my senses. I made peace in my heart and returned to church. (p. 110-112) 
The death of her fiancé in 2001 resulted in the loss of a significant attachment in Chiya's life. McCall (2004:34) states that all people have numerous positive attachments that make up the web of their lives. These attachments, connections and relationships help to define and shape who we are. When any of these attachments, connections, or relationships is threatened or becomes separated, we experience loss - and our response to this loss is grief. Collins (1988:345) acknowledges that this grief is never easy. While we may try to soften the trauma of loss by dressing up the corpse, surrounding the body with flowers or soft lights, and using euphemisms like 'pass away' or 'departed' instead of 'died' we cannot make death into something beautiful. In 2001 Chiya struggled to come to terms with the loss of her fiancé.

In her story, Chiya (2013) refers to her grandmother's role in laying the foundation of her images and conceptions of God. She says that her grandmother instilled faith in God in her while she was growing up and that it was her grandmother who taught her that God is always there and that he will always answer your prayers. She demonstrated this belief in acts of prayer and in practising rituals (like praying for water), even when this was contrary to other's beliefs in the works of the sangomas [traditional healers]. She (2013) was taught that:

If you pray and it doesn't happen don't lose heart because it's not only you who is praying, other people are praying too and everybody has their turn. I mustn't move from my position because my turn will come. It will be embarrassing to God if you go to sangomas and when He comes with your blessings you have moved. (pp. 113-115)

She (Chiya 2013) adds:

This influenced my life in that if I break up with a boyfriend I will not lose [heart]. I never touched muthi [traditional medicine] to get him back. Grandmother had no specific time to pray. Before going to sleep the whole house prayed, midnight she would wake up alone to pray; at 4am she woke us up to pray. We got used that we could even join her at midnight prayer. She was like a born-again. When she told us stories they were stories from the word of God. (pp. 110-114)

Chiya learnt spiritual discipline, which carried her through difficult times, and especially when she lost loved ones, friends and boyfriends. She lost two fiancés to death and yet this did not crush her God-images. While some people drift away from God because of the tragic loss of even one person, Chiya's losses brought her closer to God.

\section{She (Ciya 2013) writes:}

I saw God as the creator who needs to be praised all the time and that everything happens for a reason. There is scripture in the Bible that says: 'I knew you when you were still in your mother's womb and I counted your days.' Who am I to question Him? I love God more than anything and know that through Him everything is possible. (p. 113)

However, as with many believers in God who are tested, Chiya's turn had come. Her third fiancé's condition took a toll on her faith in God, as she pleaded with him for him to recover. She (Chiya 2013) says:

I stayed with him morning till night. Whenever I tried to pray my sorrows were flooded in tears. I asked God, 'Ukuthi, why mina?' [Why me?] When will I find happiness in my life? (p. 114)

On Tuesday, 27 March 2001 she received the news that her fiancé had died. She (Chiya 2013) says:

His death put my life on hold. On 1 April 2001 his body was laid to rest in Howick Cemetery, the saddest day of my life. I told myself that God did not love me so I broke away from church for almost two years. I did not pray and if anyone mentioned God, I swore. (pp. 113-114)

\section{Spiritual injury}

Chiya sustained spiritual injury due to the traumatic loss of her third fiancé. Louw (2000:397) states that 'intense pain creates the impression that God is absent'. It is not surprising that after the loss of three fiancés, Chiya's spirit and Godimages were crushed. Just like Wiesel (1965:43-44) who felt forsaken by God in the Holocaust, or Jesus Christ who cried out on the cross 'My God, my God, why have you forsaken me?' (Mt 27:46 NIV), Chiya felt the bitterness of being forsaken by God. The anthropomorphic God-images (Louw 2000:329-330) that God is All-powerful and that 'nothing is impossible if you believe in God' were shattered when God did not heal her fiancé. She was so angry with God that she told herself that he did not love her anymore and therefore broke away from the church for almost two years. She adds that she stopped praying and when anyone mentioned God in her presence, she swore. In an interview on 25 April 2015, Chiya was asked why she swore. She (Chiya 2013) responded as follows:

God is a fool; He doesn't think straight; I used to deny when people say God is not there but I now agree - if He was alive my fiancé wouldn't die. Every Sunday I didn't move I didn't go to church, if you wanted to pray I used to say go and pray outside. (p. 116)

When asked what the most painful part of her fiancé's death was, and what drove her to forsake God and her spiritual support systems, Chiya revealed that she struggled most with losing the things that she and her fiancé had shared, which cannot be shared with anyone else. She added that this was made worse by the death of a friend, which left her with no one with whom she could share. Lamenting the loss of her fiancé, Chiya (2013) says:

I could sit and relax knowing [that] he listens to me, defend me even if I did wrong, then later he could tell me where I was wrong, he came to my level not as someone who is better than me, he was encouraging me how to be sustainable, allowing to be my own, building my career and suddenly he is gone. It's like all my dreams were shattered, everything just went blank. (pp. 115-116)

She not only sustained spiritual injuries, but her fiancé's death also affected her psychologically, socially and 
behaviourally (biopsychosocial effects). She (Chiya 2013) says:

I would go to bed without praying, I didn't know what type of a person I was without prayer. It was like it was not myself. But when I came back I started feeling that the real person had come back. The real me went out, I was irritable. After fasting the real Manakhe [her name] came back. (pp. 114-115)

I lost a sense of being a good person, good mother, who loves her family. If one did something bad I said bad things to hurt the other. I wasn't myself. Thank God that I didn't drink or smoke. But I know the prayers of my grandmother helped to get me back. (p. 116)

\section{Chiya (2013) adds:}

I had no manner of talking to people. I used to be [by] myself [with] no friends; if you don't have love you don't have anything. I didn't care about anyone. If I heard that someone died, I didn't sympathise with anyone, I didn't care. I don't remember smiling even when someone cracked a joke. It's like I was victim and people were gossiping about me. (p. 116)

Although Chiya's problem was the result of shattered God-images, the impact of this affected other domains of her life. She became anti-social, irritable and aggressive and did not care or have compassion for other people and their feelings. The woman who once comforted those who lost their loved ones, did not care anymore. Thus her vertical relationship with God affected her horizontal relationships with other people. Support systems are very significant in the recovery from trauma and yet she shut herself off from these systems. She did not stay in this state forever. Like the estranged prodigal son (Lk 15) who came back home from the wilderness, Chiya returned to God in a very dramatic way.

\section{Return from the wilderness}

Although Chiya acknowledges that she was bitter towards God, she concedes certain positive events were the acts of God. For example Chiya was especially bitter about the fact that her fiancé was the only breadwinner at home and his passing meant losing that income. However, a few months after his death she got a job at Northway Spar in Northdale, Pietermaritzburg. Chiya was invited to an interview for the position, but upon arrival, instead of being interviewed, she was asked to start working that morning. She (Chiya 2013) explains:

[On] 27 March 2001 my fiancé passed away, and gogo (grandmother) challenged me that 'you see what God has given you. You have a job and whatever he [late fiancé] was providing for you the job is providing. Don't you think that God has answered your prayer?' I said no it just [had] to be. Gogo argued, 'who made it to be?' So I concluded that God was there. (pp. 114-116)

Then one Sunday her cousin invited her to attend church. What was strange was that on this particular Sunday she accepted, even though she refused to go to church previously. She (Chiya 2013) says:
So I went but refused to wear my church uniform. As I heard the word of God, there was an inner argument inside me. The preacher rambled: 'If it doesn't happen to you, who else? It was meant to happen to you at a particular time.' He said 'before you were born God had planned everything about your life so what you are experiencing now was planned.' Then I came to my senses that while I was in my mother's womb God planned and so what is happening to me now is a proof of God's plan. I started thinking that if the things I plan don't succeed it means God didn't plan for me. This was a new teaching, revelation because I never thought about this before. It was like the first time I heard such a preaching - everything was like new to me. (p. 116)

On that day, Chiya made peace with God and returned to the church. She (Chiya 2013) consequently decided to perform religious rituals to restore her relationship with God:

I asked my cousin if we can have a dry fast [fasting] for a week because I have wronged God for so long. I want to repent and tell God that I was a fool though I thought that you [God] were a fool - can you please hold me in your hands. I made a decision, vow: I will pray [to] God until I die, nothing will ever distract me from praying to God even if I lose my child or whatever, I won't stand back. Fasting happened - we used to go to pray two times a day - morning and evening. I was told I could work for two weeks but I worked for six years. For me this was God magic. (p. 116)

Strangely enough, when Chiya returned to God and restored her spiritual support system, the biopsychosocial symptoms related to her trauma and which were complicated by her grief disappeared. She did not seek psychological, psychiatric or social work services - instead she performed the rituals of repentance, prayer, fasting and reconnected with the church. Herman (1992:133) maintains that the core experiences of psychological trauma are disempowerment and disconnection from others. Recovery, therefore, is based upon the empowerment of the survivor and the creation of new connections.' Herman (1992) adds that:

having come to terms with the traumatic past, the survivor faces the task of creating a future. She has mourned the old self that the trauma destroyed; now she must develop a new self. Her relationships have been tested and forever changed by the trauma; now she must develop new relationships. (p. 196)

Chiya's case demonstrates this point, as she was able to reconnect with her religious support system, and subsequently recovered from the biopsychosocial and spiritual effects of the traumatic death of her fiancé.

\section{Discussion}

\section{Link between trauma and spirituality}

This study set out to answer the questions: Why is it that spirituality and God himself seem to make little or no sense to people who are experiencing trauma? Do people's understanding of God and what they believe about his nature and power also affect their spirituality and determine how they understand God's intervention in coping with trauma? Evidence from Chiya's case and other studies suggests that spirituality and our understanding of God affect whether and 
how we cope with trauma or existential crises. Herman (1992:95) argues that traumatic events destroy the survivor's faith in a natural or divine order and cast the survivor into a state of existential crisis. This view is supported by Buckenham (1999:7-8) who argues that trauma wreaks emotional, psychological and spiritual havoc in a person's life and their relationships with themselves, others and God. Herman (1992:93) adds that prolonged, repeated trauma invades and systematically breaks down structures of the self - the image of the body, the internalised images of others, and the values and ideals that lend a person a sense of coherence and purpose. 'These profound alterations in the self and in relationships, inevitably result in the questioning of basic tenets of faith' (1992:94). He (1992) provides support for this assertion by citing an example of prisoners in the Nazi concentration camps that had strong and secure belief systems and could endure the ordeals of imprisonment and emerge with their faith intact or strengthened. This is, however, only true for an extraordinary few, and the majority of people experience the bitterness of being forsaken by God. To demonstrate this, Herman (1992) cites Wiesel (1965), a holocaust survivor, who expresses this bitterness in his book, Night:

Never shall I forget those flames which consumed my faith forever. Never shall I forget that nocturnal silence which deprived me, for all eternity, of the desire to live. Never shall I forget those moments which murdered my God and my soul and turned my dreams to dust. Never shall I forget, even if I am condemned to live as long as God Himself. Never! (pp. 43-44)

Wiesel struggles to understand God in the midst of the brutality of the Nazi concentration camps. In his play titled, The trial of God, which was staged on 25 February 1649 in Shamgorod, Ukraine and recorded by Wiesel (1979), he exposed how people's understanding of God and what they believe about his nature and power affect human spirituality and their understanding of God's intervention in traumatic situations. Although the setting of the play is fictional, and the play's notes indicate that it 'should be performed as a tragic farce' (Wiesel 1979:xxv), Wiesel witnessed first-hand the events that he based the story on as a teenager in Auschwitz. In his play, Wiesel grapples with the following theodicy question: Where is God when innocent human beings suffer? (Manda 2013:277). Louw (2000:332) adds that a tragic story can become problematic, especially when the victim's feelings of powerlessness and helplessness are projected onto God in such a way that he is experienced as being far away and disinterested. Thus, although the trial itself reveals an awful truth about the classical Jewish concept that 'we are punished because of our sins' (Horowitz 2006:81), a core concern in The trial of God is the question of how (if at all) people can understand God to be just and good in the light of the suffering of the innocent that is pervasive in the world (Manda 2013:278). Wiesel (1979) argued that:

any God worthy of the name would not only refuse to condone such brutality but would expend all the divine effort necessary to bring the brutality to a halt, and initiate the work of passionate rebuilding. (p. viii)
Could the struggles that Chiya, Wiesel and Brown experienced suggest that spirituality itself is an abstract concept that lacks practical relevance in crisis situations? Wilson and Moran (1998:168-178) maintain that the faith that God is constantly available to respond to one's hopes, fears, anxieties, and tragedies can be shattered'. When this faith is shattered, 'individuals who are unable to resolve challenges to their moral and spiritual beliefs might find themselves in a state of spiritual alienation' (Nelson-Pechota 2004), or what Louw (2007:72) calls, 'spiritual illness'. This alienation or spiritual illness can take many forms. For example Drescher and Foy (1995:1) explain that traumatic events often lead to dramatic changes in survivors' worldviews so that fundamental assumptions about meaningfulness, goodness and safety shift negatively. They add that 'for those whose core values are theologically founded, traumatic events often give rise to questions about the fundamental nature of the relationship between creator and humankind' (1995:1). In other words, Grant (1999) postulates:

traumatic experiences force victims to face issues lying outside the boundaries of personal and collective frames of reference. As a result, they are forced to confront psychological and spiritual challenges that are unfamiliar to the average person.

Sherman (2010:37) argues that is it for this reason that traumatic events call into question basic human relationships, breach attachments of family, friendship, love and community, shatter the construction of the self that is formed and sustained in relation to others, and undermine the belief systems that give meaning to human experiences. In this way, spirituality may be viewed as an abstract concept that lacks practical relevance in crisis situations.

This study also set out to explore if people's understanding of God, and what they believe about his nature and power, affect human spirituality. The authors also sought to investigate how people's understanding of God determines how they understand God's intervention in coping with trauma. To address these questions, the authors explored what role Godimages play in the lived religion or spirituality, healing, and well-being of people who have survived traumatic experiences. The authors reflected critically on Chiya's case study. Chiya's experience is a good example of what Louw (2000:397) calls 'dysfunctional or pathological faith-behaviour' because of spiritual injury. Louw (2000:397) contends that 'intense pain creates the impression that God is absent'. One sees this in Chiya's (2013) questions to God: 'Ukuthi, why mina?' [God, why me?] and 'When will I find happiness in my life?'; 2013:117). Louw (2000:397) clarifies that God's involvement in suffering becomes intensely problematic, especially when the believer confesses God's omnipotence. Indeed Chiya's (2013:118) conviction that ' $[n]$ othing is impossible if you believe in God' was shattered, and she consequently abandoned God and anything to do with God for two years. So deep was her spiritual injury, that she says, 'I did not pray and if anyone mentioned God, I swore'. The case shows that not only does trauma alienate its victims from friends and 
family, but it also shatters God-images and alienates its victims from God or their object of devotion.

\section{Coping with trauma from spiritual resources}

Given the above, the question that arises is: How does a person whose spiritual beliefs and meaning-making systems have been breached or shattered by trauma or crisis, recover faith or cope with trauma? The authors suggest the following, however, it should be noted that these suggestions are not exhaustive.

Firstly, the reconnection with the trauma survivor's support systems brings recovery and resilience from trauma. Herman (1992:133) maintains that recovery from trauma 'is based upon the empowerment of the survivor and the creation of new connections'. Thus, while helplessness and isolation are the core experiences of psychological trauma, Herman (1992) contends, 'empowerment and reconnection are the core experiences of recovery'. In Chiya's case, her reconnection with her spiritual support system and God, through the performance of religious rituals, ended her alienation of God. Strangely enough, when Chiya reconnected with her spiritual resources, her biopsychosocial symptoms of trauma and grief disappeared.

Secondly, a trauma survivor needs to mourn the loss sustained by the traumatic experience. Herman (1992:196) alleges that after mourning the old self that was destroyed by trauma, the survivor must develop a new self. His or her relationships having been tested and forever changed by the trauma, the survivor must focus on a new future and develop new relationships. 'The old beliefs [God-images] that gave meaning to her or his life have been challenged; now he or she must find anew a sustaining faith' (1992). We see this in Chiya's case when she returns to church and is faced with the task of creating a new future by developing new relationships at the church. While reconnecting with her religious support system, Chiya recovered from the biopsychosocial and spiritual effects of the traumatic death of her fiancé.

Thirdly, healing from trauma calls for cognitive restructuring. In order for trauma survivors to heal and recover from the state of existential crisis, DePrince and Freyd (2002:71-82) contend that the survivor must reconcile his or her old set of assumptions (or God-images) with new modified assumptions. In her book, Shattered assumptions: Towards a new psychology of trauma, Janoff-Bulman (1992:5) maintains that when confronted by events of seismic proportions, humans become psychologically distressed because traumatic events shatter some of their fundamental assumptions about the world. In this regard, Gilchrist (n.d.) states:

in facing a traumatic event, victims enter a process that leads them, ideally, to rebuild their assumptions by incorporating a new understanding of the event. They may thus continue to live with awareness that such events occur, yet without being overwhelmed by their existence.
Manda (2013:279) argues that 'traumatic events confront and sometimes shatter God-images of a survivor. That makes the reconstruction of God-images necessary if the survivor has to experience healing'. According to Manda (2010:279) the term reconstruction carries with it a notion that something has been broken, fractured, wounded and therefore it is not in the original shape or essence. Sometimes bringing it back to the original design may not be possible. This is true with the healing of individuals. However, at other times the design is modified. When God-images become dysfunctional or pathological, or when the old God-images cannot sustain the faith-behaviour, there is a need to reconstruct them (Louw 2000:48; Manda 2013:279). Louw (2000:48) is right in arguing that each person has a unique image of God which reflects his or her own experience of God and what God means to him or her personally. His or her understanding of God is influenced by subjective and existential factors. Chiya's God-images became dysfunctional and abstract because they lacked practical relevance to help her cope in her crisis situation. This resulted in her complicated grief and alienation from God and her spiritual support systems. Reconnecting with the spiritual system required the reconstruction or modification of God-images that became dysfunctional. In Chiya's (2013) case, she was challenged by the preacher's message: 'If it doesn't happen to you, who else? It was meant to happen to you at a particular time ...' (p. 114).

\section{Chiya (2013) says that:}

this was a new teaching, revelation because I never thought about this before. It was like the first time I heard such a preaching - everything was like new to me. (p. 112-114)

While we may have theological challenges with the preacher's message because it raises theological debates about predestination, the preacher's words invoked cognitive restructuring in Chiya's belief system. According to her, she came to the realisation that the losses she was so angry about were actually the results of what God had predestined for her. Whether her understanding of God was true or not, is beside the point. Her process of cognitive restructuring or the reconstruction of her God-images brought her healing and restoration from the debilitating effects of her grief.

Fourthly, whereas we do not intend this study to advocate spirituality as a tool for healing trauma, the case study, together with evidence from other studies, suggests that spiritual resources are significant for coping with trauma. For example several major meta-analytic reviews have shown that individuals who use religious and spiritual coping mechanisms demonstrate greater physical and emotional well-being (Ano \& Vasconcelles 2005; Pargament 2007). A national survey conducted by Schuster, Stein and Jaycon (2001:1505-1512) found that after the terrorist attacks of 11 September 2001, 90\% of Americans reported that they turned to prayer, religion or some other form of spiritual activity with loved ones in an effort to cope. Furthermore, a study of the survivors of Hurricane Katrina revealed that $92 \%$ of those who survived and who were evacuated to shelters in Houston 
said that their faith played an important role in helping them get through the situation (Meichenbaum n.d.:6). A further, poignant account is offered by Meichenbaum (n.d.) who describes how prisoners in concentration camps secretly continued engaging in religious activities. In his book, Wiesel (1965) describes how God was put on trial and found guilty by the prisoners of a concentration camp, who then went on to pray to the same God after the trial. Manda (2015:7) argues that people turn to spirituality because it helps them to find meaning, purpose and hope, which may nurture individuals in their suffering. Thus the use of posttraumatic spirituality may enhance self-empowerment, leading to the discovery of meaning and purpose in posttraumatic situations.

\section{Conclusion}

The study explored the theologies and spiritualities that emerge when people are confronted with traumatic events and other existential crises. It also explored whether and how spirituality could be used as a resource to address the needs of people in traumatic situations. The case study of Chiya was explored to understand why it is that spirituality and God may seem to make little or no sense to people who are experiencing trauma. The findings suggest that traumatic events destroy not only the biopsychosocial aspects, but also the survivor's faith in a natural or divine order and cast the victim into a state of existential crisis. This state of existential crisis may affect how people understand God's intervention in coping with trauma. The findings further show the role that spirituality plays in enhancing the healing, recovery and well-being of trauma survivors. Chiya, whose life history was explored in detail, mentions that her turning point from grief was the day she attended church and heard the preacher's words. She then practised spiritual rituals like prayer and fasting, and repented before God for her thinking, attitude and behaviour towards him during the traumatic loss of her fiancé. Chiya's response is consistent with the findings of other studies that investigated how the survivors of the $9 / 11$ bombings and Hurricane Katrina used their spiritual resources to cope with trauma.

While studies in the field of trauma in South Africa have focussed on the biopsychosocial approach, the authors argue for an integrated approach to understand and treat trauma survivors. The integration of spirituality into the psychotherapeutic dialogue, particularly in South Africa, where a majority of the population is exposed to trauma and PTSD, will have implications for the disciplines of practical theology and psychology and psychiatry - especially in terms of how we understand, assess and treat trauma survivors.

\section{Acknowledgements Competing interests}

The authors declare that they have no financial or personal relationships which may have inappropriately influenced them in writing this article.

\section{Authors' contributions}

Both C.M. and V.M. conceptualised the article and equally contributed to the writing and critical editing processes.

\section{References}

Ano, G.G. \& Vasconcelles, E.B., 2005, 'Religious coping and psychological adjustment to stress: A meta-analysis', Journal of Clinical Psychology 61(4), 461-80, viewed 22 October 2013, from http://www.ncbi.nlm.nih.gov/pubmed/15503316

Atwol, L., Stein, D.J., Williams, D.R., Mclaughlin, K.A., Petukhova, M, Kessler, R.C. \& Koenen, K.C., 2013, 'Trauma and posttraumatic stress disorder in South Africa: Analysis from the South African Stress and Health Study', BMC Psychiatry 13(192), 1-8.

Bell, A., 2003, 'A narrative approach to research,' Canadian Journal of Environmental Education 8, Spring, 200.

Buckenham, K., 1999, Violence against women: A resource manual for the church in South Africa, Pietermaritzburg Agency for Christian Social Awareness (PACSA), Pietermaritzburg.

Chiya, N., 2013, 'On my strong shoulders', in D.R. Haarhoff (ed.), Trees along the riverside: The stories of trauma facilitators in KwaZulu-Natal South Africa, pp. 107-118, Pietermaritzburg Agency for Christian Social Awareness (PACSA), Pietermaritzburg.

Collins, G.R., 1988, Christian counseling: A comprehensive guide, rev. edn., Word Publishing, Dallas.

DePrince, A.P. \& Freyd, J.J., 2002, 'The harm of trauma: Pathological fear, shattered assumptions, or betrayal?' in J. Kauffman (ed.), Loss of the assumptive world: A theory of traumatic loss, pp. 71-82, Brunner-Routledge, New York.

Drescher, K.D. \& Foy, D.W., 1995, 'Spirituality and trauma treatment: Suggestions for including spirituality as a coping resource', National Center for PTSD (NCP) Clinical Quarterly 5(1), viewed 16 February 2015, from http://montgomery.md. networkofcare. org/veterans/ library/article. aspx?id=384

Edwards, D.J.A., 2005, 'Post-traumatic stress disorder as a public health concern in South Africa', Journal of Psychology in Africa 15(2), 125-134.

Elliot, J., 2005, Using narrative in social research: Qualitative and quantitative approaches, Sage, London.

Gardner, K., 2002, Age, narrative and migration: The life course and histories of Bengali Elders in London, Berg, London.

Gilchrist, K.J., n.d., A genealogy of suffering, viewed 20 December 2012, from http:// www.inter-disciplinary.net/probing-the-boundaries/wp>content/uploads/2012/ 10/gilchristsufpaper.pdf

Grant, R., 1999, 'Spirituality and trauma: An essay', Journal of Traumatology 5(1E2), viewed 16 February 2015, from http://in-sigththerapy.blogspot.com/2013/06/ reactions-to-war-and-combat-combat.htm

Haarhoff, D.R. (ed.), 2013, Trees along the riverside: The stories of trauma facilitators in KwaZulu-Natal South Africa, pp. 107-118, PACSA, Pietermaritzburg.

Herman, J.L., 1992, Trauma and recovery: The aftermath of violence from domestic abuse to political terror, Basic Books, New York.

Hoffman L., Tifany, T., Jones, B.A., Williams, F.B.A., Kei, S., Dillard B.A., et al., n.d., 'The God image, the God concept, and attachment', viewed 21 August 2016, from http://louis-hoffman-virtualclassroom.com/Publications_Page/God\%20Image $\% 20$ http://louis-hoffman-virtualclassroom.com/Publications_Page/God\%20lmage $\%$.
$\% 26 \% 20$ Attachment $\% 20$ Vanguard $\% 20$ CAPS $\% 20$ presentation $\% 202004$.pdf

Horowitz, R., 2006, Elie Wiesel and the art of storytelling, McFarland, North Carolina.

Janoff-Bulman, R., 1992, Shattered assumptions: Towards a new psychology of trauma, Macmillan, New York.

Kaminer, D. \& Eagle, G., 2010, Traumatic stress in South Africa, Wits University Press, Johannesburg.

Kushner, H.S., 1981, When bad things happen to good people, Schocken Books, New York.

Lewis, D., 2008, 'Using life histories in social policy research: The case of third sector/ public sector boundary crossing', Journal of Social Policy 37(4), 559-578 C, doi: $10.1017 /$ S0047279408002213

Louw, D.J., 1998, A pastoral hermeneutics of care and encounter, Lux Verbi, Cape Town.

Louw, D.J., 2000, Meaning in suffering: A theological reflection on the cross and the resurrection for pastoral care and counseling, Peter Lang, Berlin.

Louw, D.J., 2007, Cura vitae: Illness and the healing of life: A guide for caregivers, Lux Verbi, Wellington.

Louw, D.J., 2013, 'Cura vitae: The hermeneutics of spiritual healing and the beautification of life', Scriptura 112(1),1-16.

Manda, C.B., 2013, 'Re-authoring narratives of trauma survivors in KwaZulu-Natal: Spiritual perspective', Unpublished PhD Thesis, Faculty of Theology, University of Pretoria, Pretoria.

Manda, C.B., 2014, 'Becoming better humans in a world that lacks humanity: Working through trauma in post-apartheid South Africa', Oral History Journal of South Africa 2(2), Nov., 123-137.

Manda, C.B., 2015, 'Re-authoring life narratives of trauma survivors: Spiritual perspective', HTS Teologiese Studies/Theological Studies 71(2), Art. \#2621, 8 pages, viewed 22 October 2015, from http://dx.doi.org/10.4102/ hts.v71i2.2621

Martin, L. \& Kagee, A., 2008, 'Lifetime and HIV-related PTSD among persons recently diagnosed with HIV', Journal of AIDS Behavior 15(1), 125-131, doi: 10.1007/s10461008-9498-6 
Mbiti, J.S., 1970, Concepts of God in Africa, SPC., London.

McCall, J.B., 2004, Bereavement counseling: Pastoral care for complicated grieving, The Haworth Pastoral Press, New York.

Meichenbaum, D., n.d., Trauma, spirituality and recovery: Toward a spiritually integrated psychotherapy, Miami, Florida, viewed 12 November 2012, from www. melissainstitute.org

Müller, J.C., 2004, 'HIV/AIDS, narrative practical theology, and postfoundationalism: The emergence of a new story', HTS Teologiese Studies/Theological Studies 60(1/2), 293-306.

Nelson-Pechota, M., 2004, Spirituality and PTSD in Vietnam combat veterans, viewed 29 December 2012, from http://www.vietnamveteranministers.org/spirituality intro.htm

Oborji, F.A., 2008, 'African Theology, Roman Catholic', in W.A. Dyrness \& V.-M Kärkkäinen, Global dictionary of theology: A resource for the worldwide church, pp. 15-20, InterVarsity, Downers Grove.

Olley, B., Seedat, S. \& Stein, D.J., 2006, 'Persistence of psychiatric disorders in a cohort of HIV/AIDS patients in South Africa: A 6-month follow-up study', Journal of Psychosomatic Research 61(4), 479-484.

Pargament, K.I., 2007, Spiritually integrated psychotherapy: Understanding and addressing the sacred, Guilford Press, New York.
Schneider, J.H., 1997, 'Zur Entwicklung, Wandlung und Reifung von Gottestellungen' Batechetische Blatter 4, 222-231.

Schuster, M.A., Stein, B.D., Jaycon, L.H., 2001, 'A national survey of stress reactions after the September 11, 2001, terrorist attacks', New England Journal of Medicine $345,1507-1512$.

Sherman, N., 2010, The untold war: Inside the hearts, minds, and souls of our soldiers, Norton, New York.

Stevens, R.P. \& Green, M, 2003, Living the story: Biblical spirituality for everyday Christians, Eerdmans, Grand Rapids.

Waaijman, K., 2003, Spiritualiteit: Vormen, grondslagen, methoden, Carmelitana, Gent. Wacheche, P., 2012, Modern trends in Christianity, MA dissertation, Faculty of Theology, Nairobi University, Nairobi.

Watson, L.C. \& Watson-Franke, M.B., 1985, Interpreting life histories: An anthropological enquiry, Rutgers University Press, New Jersey.

Wiesel, E., 1965, Night, trans. S. Rodevy, Hill \& Wang, New York.

Wiesel, E., 1979, The trial of God, (as it was held on February 25, 1649, in Shamgorod), Random House, New York.

Wilson, J.P. \& Moran, T.A., 1998, 'Psychological trauma: Posttraumatic stress disorder and spirituality', Journal of Psychology \& Theology, 26(2), 168-178. 